\title{
Depression of viral interferon induction in cell monolayers by coal dust
}

\author{
NICHOLAS HAHO,N ${ }^{1}$ \\ Appalachian Laboratory for Occupational Respiratory Diseases and the Departments of \\ Microbiology and Pediatrics, West Virginia University School of Medicine, Morgantown, \\ West Virginia, 26505, USA
}

\begin{abstract}
Hahon, N. (1974). British Journal of Industrial Medicine, 31, 201-208. Depression of viral interferon induction in cell monolayers by coal dust. Studies on the induction of interferon by influenza virus revealed that this adaptive cellular response was depressed completely or partially in coal dust-treated human or simian cell monolayers. Maximal inhibition of interferon production occurred with coal particles ranging in size from $<2 \cdot 0$ to $19 \cdot 1 \mu \mathrm{M}$ and with coal dust concentrations ranging from 0.1 to $0.001 \mathrm{~g}$ per $3 \times 10^{7}$ cells. The longer coal dust remained in contact with cells before the addition of viral inducer, the more likely was interferon production inhibited. Interferon depression was independent of the rank and geographic source of coal dust and of the virus/cell multiplicity of infection. Enhanced interferon yields resulted in normal and coal dust-treated cells when they were pretreated or primed with interferon. Neither interferon antagonists, interference with virus-cell integration, nor adsorption by coal dust accounted for the depression of interferon yields. The data suggest that coal particles per se act on cells in a subtle manner to interpose in the inductive process of interferon synthesis.
\end{abstract}

Within recent years the influence of respiratory irritants, i.e., atmospheric pollutants and cigarette smoke, on the pathogenesis of both bacterial and viral respiratory infections has been the subject of increased experimental investigation. It has been established through the use of infectious diseaseanimal model systems (Coffin, 1972; Ehrlich, 1966; Spurgash, Ehrlich, and Petzold, 1968; Henry, Findlay, Spangler, and Ehrlich, 1970) that a number of environmental factors diminish the resistance or ability of the lung to cope with introduced infectious agents. Exclusive of extensive investigations on the association of pulmonary tuberculosis with varied types of pneumoconiosis (Zaidi, 1969), few experimental studies have been reported on the effect of non-oxidant particles on the course of pulmonary infections or concomitant humoral and cellular responses (Coffin, 1972). Increased mortality rates

${ }^{1}$ Reprint requests to ALFORD, Box 4292, Morgantown, West Virginia, 26505, USA from bronchitis have been noted in coal miners and their wives in comparison with non-miners and their wives (Registrar-General's Decennial Supplement, 1951). Although the evidence is tenuous, it has been suggested that miners and their wives may be more susceptible to respiratory infections. The rôle of respiratory virus infections in relation to coal workers' pneumoconiosis remains unsettled because neither sufficient experimental nor epidemiologic data are available to assess its significance.

The findings of Acton and Myrvik (1966) suggested that cellular resistance mediated by interferon may play an important defence rôle in viral respiratory infections. They demonstrated that rabbit alveolar macrophages produced classical interferon when exposed to parainfluenza-3 virus in vitro and that this substance passively protected other macrophages from infection with virulent rabbitpox virus. Equally relevant was the observation that nitrogen dioxide, an important component of air pollution, inhibited 
the ability of rabbit alveolar macrophages to produce interferon which resulted in a loss of cellular resistance to infection by challenge virus (Valand, Acton, and Myrvik, 1970).

In an attempt to explore the influence of coal dust on viral-induced resistance at the cellular level, a study was initiated using as the host cell system either simian or human cell monolayers. It was recognized by Harington (1972) that cell cultures are conducive for work on the pathogenesis of dust diseases. Preliminary tests indicated that the selected cell systems were amenable to interferon induction by influenza virus and that the overt integrity of cells did not appear to be altered by the presence of coal dust.

This report describes the conditions affecting the response of coal dust-treated cell cultures to the induction of interferon by influenza virus.

\section{Materials and methods}

\section{Viruses}

The Ao/PR8/8/34 influenza and parainfluenza 1 (Sendai) virus strains employed in this study were obtained from the American Type Culture Collection (ATCC), Rockville, Md. Stock virus pools of each strain were prepared from chick embryonated eggs in the manner described previously (Hahon, Booth, and Eckert, 1973a). Influenza and Sendai virus pools contained $1.0 \times 10^{8}$ and $5.4 \times 10^{\circ}$ cell-infecting units (CIU) of virus per millilitre, respectively, when assayed by the immunofluorescent cellcounting procedure (Hahon, Booth, and Eckert, 1973b).

\section{Cell cultures}

Human and monkey cell lines, Chang conjunctiva clone 1-5C-4 and LLC-MK ${ }_{2}$ respectively, obtained from ATCC, and a chimpanzee lung diploid cell line SFRE:CL-1, obtained through the courtesy of Dr. S. S. Kalter, San Antonio, Texas, were used for the induction of interferon. All cell lines were propagated in plastic tissue culture flasks $\left(75 \mathrm{~cm}^{2}\right)$ with Eagle minimum essential medium (MEM) containing 10\% fetal calf serum (FCS) and maintained with MEM plus 5\% FCS.

\section{Coal dust}

Bituminous coal dust, $<7 \mu \mathrm{M}$ particles, from the Pittsburgh seam, Cambria County, Pennsylvania was generally employed in experimental studies. The source of bituminous dusts that were also tested included Elkol seam from Frontier, Wyoming; Elkhorn Nos 2 and 3 seams from Shelbianna, Kentucky; Hazard Nos 5a and 7 seams from Sassafras, Kentucky; Upper and Lower Peach Orchard seams from Ivel, Kentucky; Upper Kittanning seam from Reels Corner, Pennsylvania; Lower Kittanning seam from Seward, Pennsylvania; Pittsburgh No 8 seam from Moundsville, West Virginia; Pittsburgh seam from Fairview, West Virginia; Pittsburgh seam from Morgantown, West Virginia; Upper Freeport seam from Kingwood, West Virginia; Indiana No. 5 seam from Winslow, Indiana; and an anthracite coal from Ashley, Pennsylvania. Coal dust samples were composed of particles of which at least $70 \%$ passed through a 200 mesh sieve. Coal dust samples were steril- ized in an autoclave at $20 \mathrm{lb} / \mathrm{in}^{2}$ pressure $\left(126^{\circ} \mathrm{C}\right)$ for 15 minutes. Generally, experiments were performed in duplicate.

\section{Interferon induction}

The procedure generally employed to study the effects of coal dust on interferon induction was carried out as follows; $0 \cdot 1 \mathrm{~g}$ coal dust suspended in a $10-\mathrm{ml}$ volume of maintenance medium, $\mathrm{pH} 7 \cdot 1$, was added to plastic flasks containing complete cell monolayers which were then incubated at $35^{\circ} \mathrm{C}$ for four hours. Residual medium was decanted, and $1 \mathrm{ml}$ of influenza virus that had been ultraviolet (UV)-irradiated for from 30 to 45 seconds was added onto cell monolayers and incubated at $35^{\circ} \mathrm{C}$ for two hours. The multiplicity of infection (MOI) was approximately 10 . Inoculum was removed, $10 \mathrm{ml}$ of maintenance medium was added to each flask which was then incubated at $35^{\circ} \mathrm{C}$ for 22 hours. Supernatant fluid was decanted and centrifuged at $100000 \times \mathrm{g}$ for one hour, dialyzed against $\mathrm{HCl}-\mathrm{KCl}$ buffer, $\mathrm{pH} 2 \cdot 0$, at $4^{\circ} \mathrm{C}$ for 24 hours and then against two changes of phosphatebuffered saline (PBS), pH $7 \cdot 1$, at $4^{\circ} \mathrm{C}$ for 24 hours. Fluids were passed through Millex filters, $0.45 \mu \mathrm{M}$ (Millipore Corporation, Boston, Massachusetts) to obtain sterile preparations. Samples were stored at $-70^{\circ} \mathrm{C}$ until assayed for interferon activity. Controls consisting of cell monolayers which were not treated with coal dust were handled exactly as described above. Preparations exhibiting virus inhibitory activity possessed the biological and physical properties ascribed to viral interferons (Lockart, 1966).

\section{Interferon assay}

An immunofluorescent cell-counting assay of interferon was employed, similar in principle and in reproducibility to that reported previously (Kozikowski and Hahon, 1969). Assays were carried out in duplicate. Interferontreated cell monolayers were challenged with Sendai virus. The reciprocal of the interferon dilution that reduced the number of infected cells to $50 \%$ of the control served as the measure of interferon activity, i.e., $50 \%$ $\mathrm{ICDD}_{50}(50 \%$ infected cell-depressing dilution). With this assay system, 0.8 international reference human $(69 / 19)$ interferon units assayed as one unit.

\section{Immunofluorescence procedures}

The direct fluorescent-antibody method was used to demonstrate immunofluorescence of viral antigens in infected cells. Details of the preparation of antiserum, its conjugation with fluorescein isothiocyanate, staining technique, microscopy equipment, and infected-cell enumeration have been described elsewhere (Hahon et al., 1973b).

Determination of virus attachment and penetration These procedures have been described in detail previously (Hahon et al., 1973b).

\section{Results}

Preliminary considerations relative to coal dust and interferon induction

An initial experiment was carried out to compare interferon induction by both viable and UV- 
irradiated influenza virus in untreated and coal dust-treated cell monolayers. The viral inducer was added within 10 minutes after the introduction of coal dust to cell cultures. Results (Table 1) show that interferon production with UV-irradiated virus was depressed approximately threefold in the presence of coal dust as compared to that produced in untreated cells. Coal dust also depressed interferon induction by viable virus.

\section{TABLE 1}

Preliminary Determination of the Induction OF INTERFERON BY PR8 INFLUENZA VIRUS IN Chimpanzee lung Cell Monolayers CONTAINING COAL DUST

\begin{tabular}{clc}
\hline Coal dust & $\begin{array}{c}\text { Inducer virus PR8 } \\
\text { influenza }\end{array}$ & $\begin{array}{c}\text { Interferon } \\
\text { ICD } \text { D }_{\mathbf{5 0}} / \mathbf{m l}^{\mathbf{1}}\end{array}$ \\
\hline $0 \cdot 1 \mathrm{~g}$ & UV-irradiated & 38 \\
None & UV-irradiated & 125 \\
$0 \cdot 1 \mathrm{~g}$ & Viable & 39 \\
None & Viable & 98 \\
$0 \cdot 1 \mathrm{~g}$ & None & 0 \\
None & None & 0 \\
\hline
\end{tabular}

${ }^{1}$ Reciprocal of $50 \%$ infected cell-depressing dilution

The possibility that this phenomenon may be related to the deleterious effect of coal dust on cells per se, the binding or adsorption of interferon by coal particles, or interference by coal dust with primary virus-cell interactions was investigated. Cell monolayers, in contact with coal dust for approximately 20 hours, were stained with $0.5 \%$ trypan blue to determine the effect of coal dust on cell viability. The viability of cells did not appear to be significantly affected by coal dust. The percentage of viable cells in untreated and coal dust-treated cell monolayers was 85 and 89 , respectively. Furthermore, the ability of cells to propagate was unaffected by the presence of coal dust. When cells were cleared of the dust by serial passage and dilution, they retained their ability to produce the same quantity of interferon as untreated cell monolayers.

To determine whether the potency of interferon was adversely affected by the presence of coal dust, $1 \mathrm{ml}$ of PBS containing $0.01 \mathrm{~g}$ coal dust or PBS alone was mixed with an equal quantity of interferon. The mixtures were incubated at $35^{\circ} \mathrm{C}$ for 20 hours and then assayed for interferon activity. The titre of interferon preparations, incubated with either PBS or PBS containing coal dust, were 110 and $130 \mathrm{ICDD}_{50}$ per $\mathrm{ml}$, respectively. The results indicate that interferon was not bound or adsorbed to coal dust.

The possibility that the depression of viral induction of interferon may be the consequence of

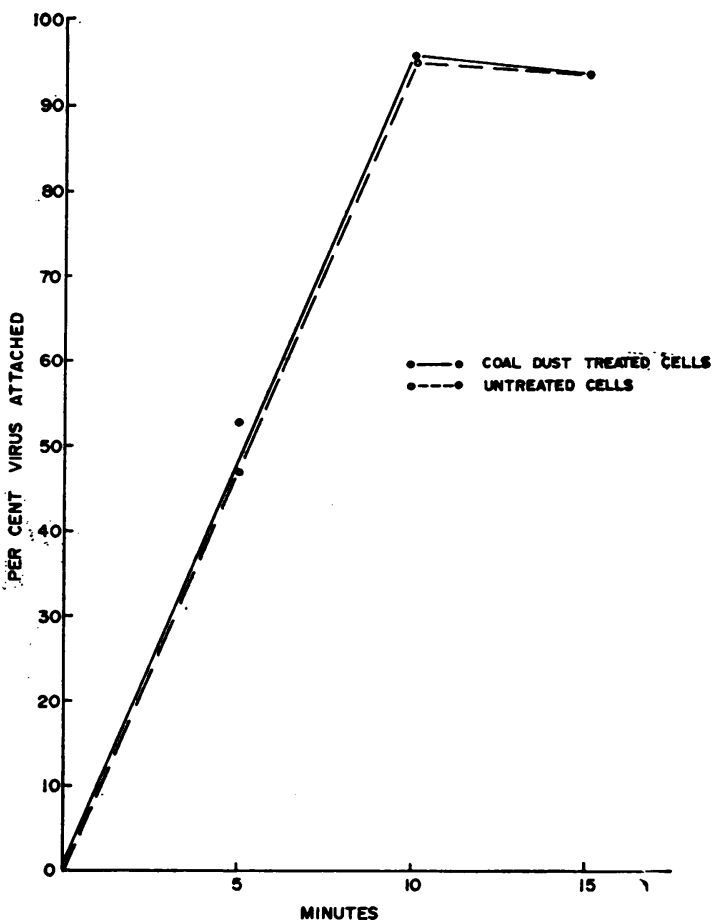

FIG. 1. Rates of attachment of PR8 influenza virus to untreated and coal dust-treated clone 1-5C-4 cell monolayer. Virus attachment was augmented by centrifugation $(13000 \times \mathbf{g})$.

an impediment of primary virus-cell interactions, i.e., attachment or penetration by the physical presence of coal dust on cell monolayers, was investigated. Results (Fig. 1) show that virus attached to both untreated and coal dust-treated cells at a similar rate and to a comparable magnitude. The presence of coal dust did not impede virus attachment. The similar rates of virus penetration into untreated and coal dust-treated cells (Fig. 2) indicate that this interaction also was not hindered by coal dust.

Fifteen bituminous coal dust samples from different geographic areas and one anthracite sample were examined for their ability to depress interferon production by influenza virus in cell monolayers. The origin of each coal sample is listed above. The results revealed that all bituminous coal dust samples, including the anthracite sample, were capable of depressing interferon production. In comparison with interferon levels in untreated cell monolayers, interferon production was depressed approximately threefold in cell monolayers treated with the different coal dust samples.

A test was designed to explore the possibility that supernatant fluid from coal dust suspensions contain soluble ingredients that may be directly responsible 


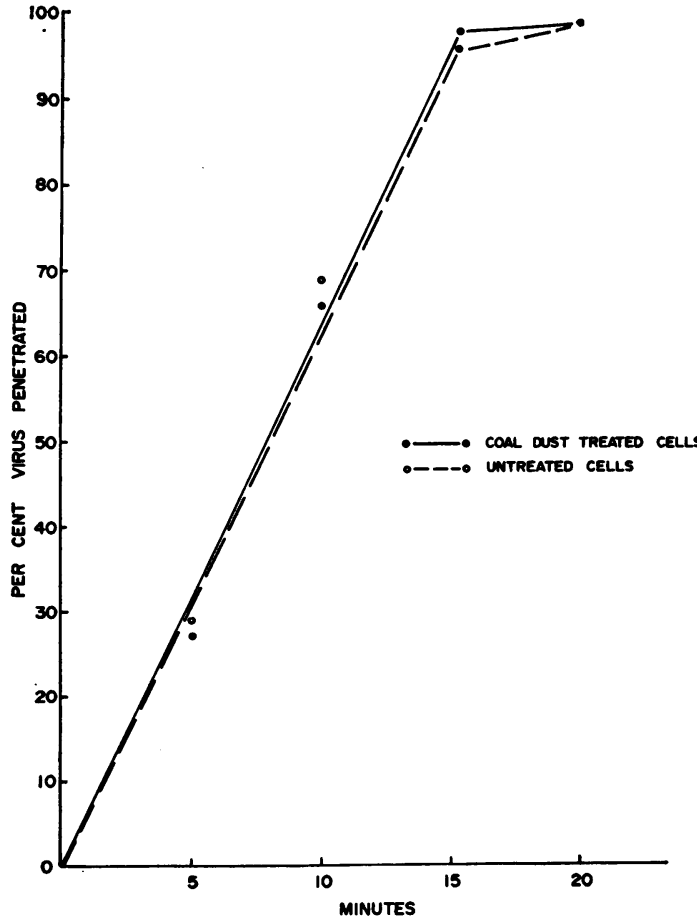

FIG. 2. Rates of penetration of PR8 influenza virus to untreated and coal dust-treated clone 1-5C-4 cell monolayers as measured by insensitivity of attached virus to antiviral serum.

for the observed depression of interferon production. The results (Table 2) show that interferon production by cells treated with supernatant fluid from coal dust suspensions was comparable to that of untreated (control) cells. Furthermore, depression of interferon production by resuspended coal dust was comparable to that by the original coal dust suspension. These findings indicate that the phenomenon of interferon depression in cells may be attributable to coal dust particles per se.

TABLE 2

COMPARISON OF SUPERNATANT FluID AND RESUSPENDED COAL DUST ON INTERFERON Production by PR8 Influenza Virus

\begin{tabular}{cc}
\hline $\begin{array}{c}\text { Additives to cell } \\
\text { monolayer }\end{array}$ & $\begin{array}{c}\text { Interferon } \\
\text { ICD } D_{50} / \mathbf{m l}^{\mathbf{1}}\end{array}$ \\
\hline Coal suspension & 26 \\
Supernatant fluid & 130 \\
Resuspended coal dust & 30 \\
Maintenance medium (control) & 100 \\
\hline
\end{tabular}

${ }^{1}$ Reciprocal of $50 \%$ infected cell-depressing dilution
Effect of coal dust on virus multiplication

The growth of influenza virus concomitant with interferon production was investigated in both untreated and coal dust-treated $\left(0.002 \mathrm{~g} / 3 \times 10^{5}\right)$ LLC-MK 2 cells. The rate of virus growth was similar in both untreated and coal dust-treated cells (Fig. 3) but reached a higher level in cell cultures containing coal dust. Coal dust-treated cells produced $0.3 \log _{10}$ unit of virus more than untreated cells. Interferon was first detected approximately 16 hours after virus infection of untreated cells, and its production reached a plateau at 30 hours. Minimal amounts of interferon (less than one unit per $\mathrm{ml}$ ) were detected in coal dust-treated cells throughout the 48-hour sampling period. These data infer that the higher level of virus growth attained in coal dust-treated cell cultures may be the consequence of the depression of interferon production.

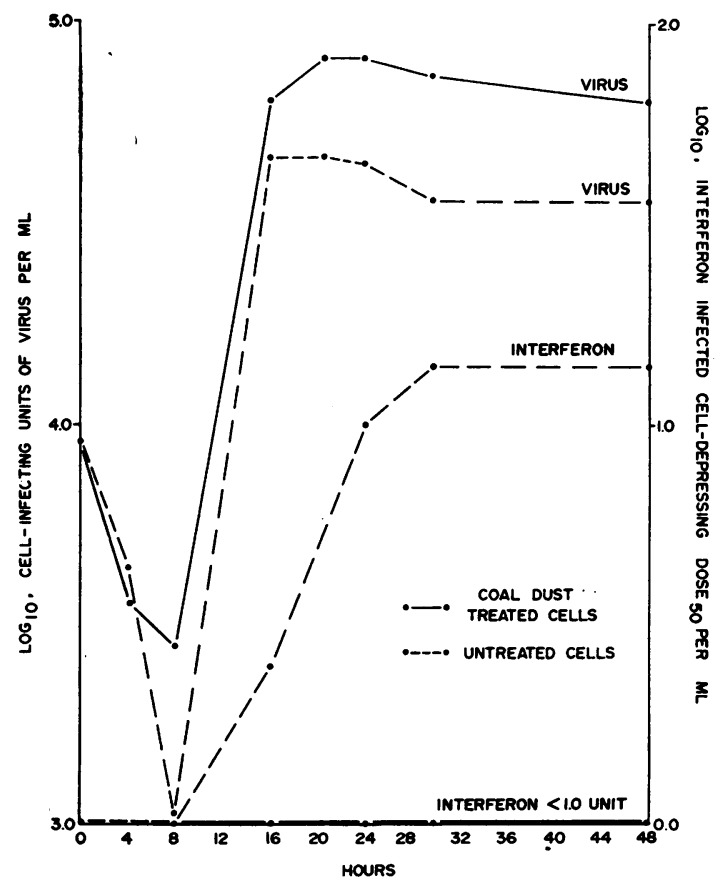

FIG. 3. Growth curves of PR8 influenza virus concomitant with interferon production in untreated and coal dust-treated LLC-MK $\mathrm{M}_{2}$ cell monolayers.

Interferon induction with coal particles of different size

Viral induction of interferon was determined with clone 1-5C-4 cell monolayers that had been exposed to coal particles ranging in size from $<2.0$ to a maximum of $74.0 \mu \mathrm{M}$. Classification of particles was accomplished with a BAHCO Microparticle 
Classifier (H. W. Dietert Co., Detroit, Michigan). For testing, each coal dust sample contained particles of different $\mu \mathrm{M}$ size as follows: $<2.0$ to $2.0,2.0$ to $3 \cdot 2,3 \cdot 2$ to $7 \cdot 0,7 \cdot 0$ to $14 \cdot 7,14 \cdot 7$ to $18 \cdot 4,18 \cdot 4$ to $19 \cdot 1$, $19 \cdot 1$ to $20 \cdot 4$, and $20 \cdot 4$ to $74 \cdot 0$. Interferon production was depressed threefold by coal particles below $19 \cdot 1 \mu \mathrm{M}$ when compared to that of the control. Coal particles above $19 \cdot 1 \mu \mathrm{M}$ did not significantly affect interferon induction.

Interferon induction with varied concentrations of coal dust and virus

The induction of interferon by PR8 influenza virus was investigated in LLC-MK 2 cell monolayers that had been treated with different quantities of coal dust ranging from 0.1 to $0.0001 \mathrm{~g}$ per $3 \times 10^{7}$ cells. The results showed a semblance of an inverse relationship between coal dust concentration and interferon production. With the highest quantity of coal dust employed, interferon production was almost completely depressed. However, it gradually increased in the presence of lesser amounts of coal dust. Interferon production was unaffected by the presence of $0.0001 \mathrm{~g}$ of coal dust.

The effect of different influenza virus-cell multiplicities of infection on interferon induction in LLC$\mathrm{MK}_{2}$ coal dust-treated and untreated cell monolayers is shown in Table 3. In coal dust-treated cells, interferon production did not increase markedly with increasing concentrations of inducer virus. Interferon production in untreated cells doubled with tenfold increases of the virus inducer.

\section{TABLE 3}

INTERFERON INDUCTION WITH DIFFERENT VIRUS/ Cell Multiplicity of INFECTION (MOI) IN LLC-MK $\mathrm{M}_{2}$ Coal Dust-treated and UnTReated Cell Monolayers

\begin{tabular}{c|cc}
\hline \multirow{2}{*}{ MOI } & \multicolumn{2}{|c}{ Interferon $^{1}$ induction in cells } \\
\cline { 2 - 3 } & Coal dust-treated & Untreated \\
\hline 100 & 22 & 140 \\
10 & 20 & 74 \\
1 & $<10$ & 42 \\
\hline
\end{tabular}

${ }^{1}$ Reciprocal of $50 \%$ infected cell-depressing dilution per millilitre

Time relationship between coal dust and viral inducer on interferon depression

In previous experiments, marked depression of interferon induction was demonstrated when coal dust was added to cell monolayers four hours prior to the introduction of inducer agent. Whether this phenomenon is time related, that is, influenced by the sequence of coal dust and viral inducer administration onto cell monolayers, was determined using clone 1-5C-4 and chimpanzee lung cell lines. The results (Table 4) reveal that only minimal amounts of interferon were produced by clone $1-5 \mathrm{C}-4$ cells when coal dust was added several hours earlier than or at the same time as the viral inducer. The longer the viral inducer was in contact with cells before the addition of coal dust, the greater was the yield of interferon. The trend was similar with chimpanzee lung cell monolayers; however, interferon production was generally greater than that noted with clone $1-5 C-4$ cells. These findings indicate that the depression of interferon production by coal dust is time related.

\section{TABLE 4}

Time Relationship between Coal Dust and PR8 INFLUENZA Virus ON DEPRESSION OF INTERFERON

\begin{tabular}{c|cc}
\hline $\begin{array}{c}\text { Hourly relation between } \\
\text { coal dust and addition } \\
\text { of virus at O time }\end{array}$ & $\begin{array}{c}\text { Interferon production, } \\
\text { ICD } D_{50} / \text { m }^{3}\end{array}$ \\
\cline { 2 - 3 } & $\begin{array}{c}\text { Clone } 1-5 C-4 \\
\text { cells }\end{array}$ & $\begin{array}{c}\text { Chimpanzee } \\
\text { lung cells }\end{array}$ \\
\hline-8 & $<10$ & $<10$ \\
-4 & $<10$ & 23 \\
0 & $<10$ & 37 \\
4 & $\mathrm{ND}^{2}$ & 58 \\
8 & 30 & 80 \\
16 & 47 & 110 \\
20 & 60 & $\mathrm{ND}$ \\
24 & 85 & 150 \\
\hline
\end{tabular}

${ }^{1}$ Coal dust $(0 \cdot 1 \mathrm{~g})$ suspended in $10 \mathrm{ml}$ maintenance medium was added to $75 \mathrm{~cm}^{2}$ flasks containing cell monolayers at designated hours prior to or after the addition of UV-irradiated PR8 influenza virus at 0 time

${ }^{2}$ Not determined

${ }^{3}$ Reciprocal of $50 \%$ infected cell-depressing dilution

\section{Priming of coal dust-treated cell cultures}

Priming or enhancement of interferon production in cell cultures by pretreatment with small amounts of interferon, before the addition of an inducer agent, has been reported with several systems (Vilček, 1969). An experiment was carried out to determine the influence of coal dust on the priming of chimpanzee lung cells for interferon induction by PR8 influenza virus. Prior to the introduction of the primer (100 units of human interferon) cell monolayers were first treated with coal dust for four hours. The results (Table 5) show that with untreated cells more than a threefold increase in interferon yield occurred 
TABLE 5

Influence of Coal Dust on the Priming of Chimpanzee lung Cells for Interferon INDUCTION BY PR8 INFLUENZA VIRUS

\begin{tabular}{lllc}
\hline Coal dust & \multicolumn{1}{c}{ Primer } & Inducer & $\begin{array}{c}\text { Interferon } \\
\text { ICD } D_{\text {50 }} / \text { m }^{\mathbf{l}}\end{array}$ \\
\hline $0.1 \mathrm{~g}$ & Interferon, 100 units & UV-PR8 & 90 \\
$0 \cdot 1 \mathrm{~g}$ & None & UV-PR8 & 37 \\
None & Interferon, 100 units & UV-PR8 & 280 \\
None & None & UV-PR8 & 80 \\
None & Interferon, 100 units & None & 0 \\
\hline
\end{tabular}

${ }^{1}$ Reciprocal of $50 \%$ infected cell-depressing dilution

in primed cell monolayers as compared to that of cells that were not stimulated. With coal dusttreated cell cultures, priming also resulted in almost a threefold increase of interferon yield when compared to similarly treated cells that were not primed. In the presence of coal dust, however, the interferon yield was significantly lower than that attained with untreated cell monolayers irrespective of priming. These data indicate that the presence of coal dust did not interfere with the ability of cells to react to the stimulating influence of the primer. Coal dust did interfere, however, with the ability of cells to produce interferon under the direction of the viral inducer.

Attempts to detect interferon blockers and antagonists That the presence of coal dust on cell monolayers may evoke the formation of a blocker or antagonist of interferon induction or activity was investigated in a series of tests. An experiment was performed to determine whether the interaction of virus with cells to induce interferon is blocked by a soluble complex resulting from an earlier cellular response to coal dust. Supernatant fluids from untreated clone $1-5 \mathrm{C}-4$ cell monolayers and from cells that were incubated at $35^{\circ} \mathrm{C}$ for four hours with coal dust were introduced onto new cell monolayers. After incubation at $35^{\circ} \mathrm{C}$ for four hours, cell monolayers were then incubated with the viral inducer for two hours and thereafter they were treated as described previously. The results of subsequent assays for interferon showed that supernatant fluids from coal dust-treated cell monolayers, in comparison with controls, did not significantly affect the induction of interferon by virus in new cell monolayers. Supernatant fluids employed in the previous experiment were examined for the presence of an antagonist of interferon activity. Dilutions of a known interferon preparation were made in both supernatant fluids from untreated and coal dust-treated cell cultures. The comparable interferon titres attained with both test preparations indicate that supernatant fluid from coal-dust cells did not contain an interferon antagonist.

An additional experiment was carried out to determine whether an interferon antagonist was present in viral-induced interferon prepared from coal dust-treated cell monolayers. This could account for the low levels of interferon activity noted in these preparations. An equal volume of either maintenance medium or undiluted low-titre interferon obtained from coal dust-treated cell cultures was added to dilutions of a standard interferon preparation, and the mixtures were then assayed for interferon activity. The titre of the standard interferon was not diminished when assayed in the presence of viral-induced interferon from coal dusttreated cells.

To explore the possibility that cell membranes may be modified by coal dust so that the release of interferon is impeded, interferon determinations were made of the intracellular contents of both untreated and coal dust-treated cell monolayers. Viral induction of interferon was carried out in cell monolayers in the described manner. To remove residual extracellular interferon, cell suspensions were subjected to three cycles of alternate centrifugation and washing with PBS. Cells were then lysed by sonic treatment. The resultant suspensions were subjected to interferon characterization and assayed for interferon activity. The results revealed that small and equivalent amounts of interferon were found in intracellular suspensions of both coal dust-treated and control monolayers. Apparently the presence of coal dust did not inhibit the release of intracellular interferon.

\section{Discussion}

The experimental obsverations described in this study show that coal dust is capable of depressing, completely or partially, an adaptive cellular response, that is, the viral-induction of interferon. The phenomenon clearly was not related to either interference with virus attachment to or penetration into cells, or the overt modification of cellular integrity by coal dust. Cells were capable of propagating in the presence of coal dust and, when cleared of the particles, the amount of interferon produced by these cells was comparable to that of normal cells. The fact that both cellular attachment and penetration of virus were unimpaired in the presence of coal dust attests to the integrity of cell membranes in relation to these early virus-cell interactions. Furthermore, virus growth proceeded at a comparable rate in coal dust-treated and in normal cells. These observations substantiate the belief that coal dust did not affect the processes of virus integration into or multiplication in cells. Coal dust, irrespective 
of rank, has been reported to be an excellent absorptive surface for proteins (Wagner, 1972), and this was considered in attempting to account for the low interferon levels that were noted in this current study. Our findings indicated that interferon was not bound or adsorbed to coal dust in any significant amount.

The depression of interferon synthesis in cell monolayers was attributatle to coal dust particles per se. There was no evidence to suggest that a soluble ingredient or complex was responsible. Supernatant fluid from coal dust suspensions did not inhibit viral-induction of interferon. Furthermore, the depression of interferon was not confined to a particular rank or source of coal. Fifteen bituminous coal samples from different geographic sites and one anthracite sample all appeared equally capable of inhibiting interferon production. Within specified limits, the ability to depress viral-induction of interferon was related to particle size and concentration of coal dust. Maximal and equivalent inhibition of interferon production occurred with coal particle sizes ranging from $<2.0$ to $19.1 \mu \mathrm{M}$. The size of these particles encompasses the range found in respirable coal dust samples, i.e., from $7 \cdot 1$ to less than $1.0 \mu \mathrm{M}$ (Corn et al., 1972). Coal dust having a particle size of approximately $7.0 \mu \mathrm{M}$ and ranging in concentration ffrom 0.1 to $0.001 \mathrm{~g}$ per $3 \times 10^{7}$ cells markedly depressed viral-induction of interferon. It was demonstrated that this latter event was also time-related. The longer coal dust remained in contact with cell monolayers before the addition of viral inducer, the more likely was interferon production to be inhibited. Conversely, the longer the viral inducer was in contact with cells before the addition of coal dust, the greater was the yield of interferon.

The ability of coal dust to depress interferon induction was not related however to virus/cell multiplicity of infection. Whereas interferon production in untreated cells doubled with tenfold increases of viral inducer, interferon production remained depressed in coal dust-treated cells regardless of the concentration of viral inducer.

Interferon pretreatment of cells to enhance interferon yields, referred to as 'priming', was demonstrated in the virus-host cell system employed. Priming can modify interferon production in three ways: it can (1) enhance the amount of interferon produced, (2) inhibit interferon production, or (3) induce interferon production at an earlier time (Stewart, Gosser, and Lockart, 1971). Priming with human interferon resulted in an increase of interferon yield not only in normal chimpanzee lung cells but also in coal dust-treated cells. Whereas coal dust affects the cells' ability to produce interferon in response to a viral inducer, it is significant that coal dust did not impair the potentiating effect of the primer on cells to enhance interferon production. Human interferon was capable of priming simian cells. This demonstration of priming activity of interferons on heterologous cells may be an exception to the general observations. Stewart et al. (1971) were unable to demonstrate priming by either mouse interferon on human or monkey cells, or chick interferon on mouse cells. Cross-reactivity between human and simian cells by heterologous interferons has been reported (Bucknall, 1967). In part, this was confirmed by our assessment of monkey interferon on human cells. These examples of reactivity between interferon and cells in heterologous systems may be attributable to some common primate determinant.

Attempts to detect a blocker (Vilček, 1969) or nonviral antagonist (Friedman and Sonnabend, 1970) of interferon induction or activity in either supernatant fluids from coal dust suspensions or in low-titre interferon preparations from coal dusttreated cells were not successful. Nevertheless, the possible existence of an anti-interferon substance cannot be discounted completely in considering the depression of interferon production under the experimental conditions described. Neither was the possibility realized that cell membranes may be modified by coal dust so as to impede the release of intracellular interferon.

Steroid hormones, carcinogenic hydrocarbons, and other agents have been reported to inhibit interferon synthesis (Vilček, 1969). Coal dust was found to contain natural oils and the hydrocarbon 3:4-benzpyrene which are readily eluted by serum (Harington and Smith, 1964). Whether 3:4-benzpyrene, like the carcinogenic hydrocarbons, plays a rôle in the depression of interferon production has not been ascertained. Whatever the mechanism involved, the experimental data suggest that coal dust most probably acts on the cell in a subtle manner as yet undetermined to interpose completely or partially in the inductive process of interferon synthesis.

James A. Booth, John D. Stewart, and Janet Simpson provided technical assistance. Gerald Chidester, Bureau of Mines, Morgantown, supplied and classified particles of coal dust samples.

\section{References}

Acton, J. D. and Myrvik, Q. N. (1966). Production of interferon by alveolar macrophages. Journal of Bacteriology, 91, 2300-2304.

Bucknall, R. A. (1967). 'Species specificity' of interferons: a misnomer? Nature, 216, 1022-1023.

Coffin, D. L. (1972). Interaction of infectious disease and air pollutants: Influence of 'tolerance'. In Environmental Factors in Respiratory Disease, edited by D. H. K. Lee, pp. 151-173. Academic Press, New York. 
Corn, M., Stein, F., Hammad, Y., Manekshaw, S., Bell, W., Penkala, S. J., and Freedman, R. (1972). Physical and chemical characteristics of 'respirable' coal mine dust. Annals of the New York Academy of Sciences, 200, 17-30.

Ehrlich, R. (1966). Effect of nitrogen dioxide on resistance to respiratory infection. Bacteriological Reviews, 30, 604-614.

Friedman, R. M. and Sonnabend, J. A. (1970). Mechanism of action of interferon. Archives of Internal Medicine, 126, 51-63.

Hahon, N., Booth, J. A., and Eckert, H. L. (1973a). Quantitative assessment of hemadsorption by myxoviruses: Virus hemadsorption assay. Applied Microbiology, 25, 595-600.

- - , and $-(1973 \mathrm{~b})$. Cell attachment and penetration by influenza virus. Infection and Immunity, 7, 341-351.

Harington, J. S. (1972). Investigative techniques in the laboratory study of coal workers' pneumoconiosis: Recent advances at the cellular level. Annals of the New York Academy of Sciences, 200, 816-834.

- and Smith, M. (1964). Studies of hydrocarbons on mineral dusts. Archives of Environmental Health, 8, 453-458.

Henry, M. C., Findlay, J., Spangler, J., and Ehrlich, R. (1970). Chronic toxicity of $\mathrm{NO}_{2}$ in squirrel monkeys. III. Effect on resistance to bacterial and viral infection. Archives of Environmental Health, 20, 566-570.

Kozikowski, E. H. and Hahon, N. (1969). Quantitative assay of interferon by the immunofluorescent cell-counting technique. Journal of General Virology, 4, 441-443.

Lockart, R. Z. (1966). Biological properties of interferons: criteria for acceptance of a viral inhibitor as an interferon. In Interferons, pp. 1-20, edited by N. B. Finter. NorthHolland Publishing Co., Amsterdam.

Spurgash, A., Ehrlich, R., and Petzold, R. (1968). Effect of cigarette smoke on resistance to respiratory infection. Archives of Environmental Health, 16, 385-391.

Stewart, W. E. III, Gosser, L. B., and Lockart, R. Z. Jr. (1971). Priming: a non-antiviral function of interferon. Journal of Virology, 7, 792-801.

Valand, S. B., Acton, J. D., and Myrvik, Q. N. (1970) Nitrogen dioxide inhibition of viral-induced resistance in alveolar monocytes. Archives of Environmental Health, 20, 303-309.

Vilček, J. (1969). Interferon, pp. 40-46. Virology Monographs No. 6. Springer, New York.

Wagner, J. C. (1972). Etiological factors in complicated coal workers' pneumoconiosis. Annals of the New York Academy of Sciences, 200, 401-404.

Zaidi, S. H. (1969). Experimental infective pneumoconiosis. Experimental Pneumoconiosis, pp. 225-253. The Johns Hopkins University Press, Baltimore.

Received for publication 23 October 1973

Accepted for publication 28 November 1973 